\title{
MODEL KESUKSESAN IMPLEMENTASI SISTEM INFORMASI PERBANKAN UNTUK MENINGKATKAN KEPUASAN DAN KEUNTUNGAN (NET BENEFIT) PERUSAHAAN (STUDI KASUS PADA PT BANK MANDIRI (PERSERO) TBK.
}

\author{
Imanuriea Annisa Putri ${ }^{1}$ Fajar Gustiawaty Dewi ${ }^{2}$ Fitra Dharma $^{3}$ \\ ${ }^{1}$ Universitas Lampung; rieannisa@gmail.com; \\ ${ }^{2}$ Universitas Lampung Fajargd@yahoo.com \\ ${ }^{3}$ Universitas Lampung Fitradharma@gmail.com
}

\begin{abstract}
Abstrak
Perkembangan teknologi informasi yang sangat pesat, memberikan kemudahan kepada segala lapisan masyarakat untuk mempermudah kehidupannya, baik kehidupan masyarakat secara pribadi atau kehidupan masyarakat profesional. Teknologi informasi dapat diakses atau dapat digunakan untuk kepentingan yang mendasar atau kepentingan tingkat yang lebih tinggi.Informasi selalu menjadi elemen penting dalam aktivitas manusia. Sistem informasi yang tidak terintegrasi dengan baik akan berimplikasi pada hal yang tidak sesuai dengan tujuan. Seperti informasi yang diperoleh peneliti bahwa laporan keuangan Perbankan Nasional dalam beberapa tahun terakhir secara umum sangat baik, dimana dilaporkan oleh masing-masing bank pada laporan keuangan tahunannya. Tujuan penelitian ini adalah untuk menguji secara empiris pengaruh kualitas informasi dan kualitas sistem terhadap kesuksesan implementasi sistem informasi perbankan untuk meningkatkan kepuasan dan keuntungan (net benefit) perusahaan. Pengumpulan data dalam penelitian ini menggunakan metode survey online dengan menyebarkan kuesioner kepada 369 sampel menggunakan google form lalu pengujian dilakukan dengan menggunakan software SmartPLS. Hasil pengujian hipotesis menunjukkan bahwa kualitas informasi berpengaruh positif terhadap kepuasan pengguna, kualitas sistem berpengaruh positif terhadap kepuasan pengguna, dan kepuasan pengguna berpengaruh positif terhadap net benefit.
\end{abstract}

Kata Kunci: Sistem Informasi Perbankan, Net Benefit, PT Bank Mandiri Tbk

\section{PENDAHULUAN}

Perkembangan teknologi informasi yang sangat pesat, memberikan kemudahan kepada segala lapisan masyarakat untuk mempermudah kehidupannya, baik kehidupan masyarakat secara pribadi atau kehidupan masyarakat profesional. Teknologi informasi dapat diakses atau dapat digunakan untuk kepentingan yang mendasar atau kepentingan tingkat yang lebih tinggi. Informasi selalu menjadi elemen penting dalam aktivitas manusia. Dari waktu ke waktu, informasi selalu dikumpulkan, dianalisis, dan didistribusikan menjadi beberapa diferensiasi golongan serta menjadi panduan aktivitas manusia.Informasi secara tradisional, yang dulu hanya digunakan sebagai data dasar untuk diolah nantinya. Pengoptimalan fungsi informasi bisa dilakukan apabila perusahaan mengembangkan informasi tersebut dengan teknologi komputer. Penerapan komputerisasi pada perusahaan menunjang struktur perusahaan untuk semakin berkembang menjadi lebih baik karena memiliki suatu fungsi yang 
komprehensif. Komputer ialah alat bantu mengolah atau mencari informasi akuntansi yang berkarakter relevan (menunjukkan waktu) dan andal (akurat) pada saat yang bersamaan (Ismail dan Mat Zin, 2009).

Pada dasarnya Bank Mandiri dan BCA memiliki karakteristik yang serupa dimana kedua bank berperinsip pada pemberian pelayanan kepada nasabah yang meliputi segmen usaha corporate, commercial, micro retail, consumer finance, treasury international banking, dan electronic banking. Dari fenomena diatas dapat terlihat bahwa sistem informasi yang digunakan oleh Bank Mandiri saat ini belum mencapai titik yang memenuhi standar kualitas sistem informasi akuntansi. Sistem informasi dibutuhkan dalam setiap kegiatan organisasi dan faktor yang dapat mempengaruhi adalah budaya organisasi dan struktur organisasi (Kieso et al., 2007).

Dimensi struktur organisasi BCA mempunyai keunggulannya yang harus tetap konsisten dikembangkan diinternal BCA, yaitu strategi, dimana BCA dalam mengembangkan organisasinya, memiliki beberapa strategi. Selain strategi dalam mengelola sistem CRM, maka perusahaan juga harus memperhatikan ERP yang dijalankan di perusahaan tersebut. Most Competitive Price, didukung oleh struktur pendanaan dengan tingkat suku bunga yang kompetitif. Operational Excellence, menjamin efisiensi biaya dengan produktifitas dan efektifitas yang tinggi. Reliabels Resources, mensinergikan berbagai sumber daya yang berkualitas. Prudent Acquistion, analisa calon konsumen yang tajam daridua channel penjualan yang handal. Mutual Relationship, mengandalkan semua pihak dalam menjamin daya tahan pertumbuhan. BCA dalam hal ini termasuk ke dalam Functional Structure dimana fungsional struktur ini dibentuk berdasarkan fungsi masing-masing departmen. Jabatan tertinggi hirarki dikepalai oleh seorang Presiden Direktur. Segala bisnis proses dan pengambilan strategi akan di tentukan oleh Presiden Direktur. Lalu dalam hirarki BCA diatas, pembagian departemen difokuskan dalam fungsi-fungsi masing-masing. Dengan kata lain bahwa pembagian struktur organisasi menurut fungsi ini lebih mudah mengarahkan setiap bagian apa yang akan dicapai oleh masing-masing bagian.

Sedangkan pada PT Bank Mandiri (Persero) Tbk. Proses Perubahan Budaya Organisasi, dilakukan dangan Menetapkan visi yang jelas dan arah strategis. Mengembangkan pengukuran kinerja yang jelas. Tindak lanjut menuju pada pencapaian tujuan. Menghargai kinerja atas dasar keadilan. Menciptakan lingkungan kerja yang lebih terbuka dan transparan. Menghapuskan politik dalam perusahaan. Mengembangkan team spirit yang kuat melalui sejumlah core values agar proses perubahan budaya organisasi dapat berjalan dengan baik. Untuk mencapai tujuannya, PT Mandiri (Persero) Tbk. telah melakukan transformasi diberbagai aspek sehingga membutuhkan manajemen, organisasi serta tata kerja yang mendukung pencapaian tujuan tersebut karena, PT Bank Mandiri (Persero)Tbk. mempunyai tujuan mencari keuntungan, maka dikategorikan organisasi niaga.

Kondisi-kondisi yang dipaparkan di atas, menggambarkan bahwa belum terciptanya penerapan sistem informasi akuntansi yang berkualitas, yang ditandai dengan hasil pencapaian tujuan perusahaan yang masih jauh dari maksimal dibandingkan bank pesaing (BCA) dimana Laudon dan Laudon (2007) mengemukakan bahwa sistem informasi merupakan hal yang penting dalam menjalankan operasional organisasi dan kualitas informasi merupakan jaminan terciptanya kelangsungan perusahaan. Informasi yang berkualitas adalah informasi yang disampaikan secara tepat sasaran, terinci dan jelas. Jika informasi yang disampaikan tidak berkualitas maka akan menimbulkan kerugian bagi perusahaan sendiri.

Sistem informasi yang tidak terintegrasi dengan baik akan berimplikasi pada hal yang tidak sesuai dengan tujuan. Seperti informasi yang diperoleh peneliti bahwa laporan keuangan Perbankan Nasional dalam beberapa tahun terakhir secara umum sangat baik, dimana dilaporkan oleh masing-masing bank 
pada laporan keuangan tahunannya. Fokus pada PT Bank Mandiri Persero Tbk. menyatakan opini yang diberikan oleh KAP dari 2010-2018 adalah Wajar sesuai dengan Standar Akuntansi Keuangan di Indonesia. Namun, sejak tahun 2012 BPK dalam laporan auditnya untuk PT Bank Mandiri Persero Tbk. telah menemukan penyimpangan-penyimpangan khususnya pada pemberian kredit sehingga menyebabkan terjadinya kredit macet yang merugikan negara hingga sekitar Rp 1,8 Triliun dimana temuan yang sama berlanjut hingga tahun 2017.

Kondisi-kondisi yang dipaparkan di atas, menggambarkan bahwa belum terciptanya penerapan sistem informasi akuntansi yang berkualitas, yang ditandai dengan hasil pencapaian tujuan perusahaan yang masih jauh dari maksimal dibandingkan bank pesaing. Laudon dan Laudon (2007) mengemukakan bahwa sistem informasi merupakan hal yang penting dalam menjalankan operasional organisasi dan kualitas informasi merupakan jaminan terciptanya kelangsungan perusahaan. Informasi yang berkualitas adalah informasi yang disampaikan secara tepat sasaran, terinci dan jelas. Jika informasi yang disampaikan tidak berkualitas maka akan menimbulkan kerugian bagi perusahaan sendiri. Penelitian ini akan meneliti pengaruh kualitas informasi dan kualitas sistem terhadap kesuksesan implementasi sistem informasi perbankan untuk meningkatkan kepuasan dan keuntungan (net benefit) perusahaan.

\section{TINJAUAN PUSTAKA \\ 2.1 Sistem Informasi}

Penerapan komputerisasi pada perusahaan menunjang struktur perusahaan untuk semakin berkembang menjadi lebih baik karena memiliki suatu fungsi yang komprehensif. Komputer ialah alat bantu mengolahataumencari informasi akuntansi yang berkarakter relevan (menunjukkan waktu) dan andal (akurat) pada saat yang bersamaan (Ismail dan Mat Zin, 2009).

Laudon dan Laudon (2007) mengemukakan bahwa sistem informasi merupakan hal yang penting dalam menjalankan operasional organisasi dan kualitas informasi merupakan jaminan terciptanya kelangsungan perusahaan. Informasi yang berkualitas adalah informasi yang disampaikan secara tepat sasaran, terinci dan jelas. Jika informasi yang disampaikan tidak berkualitas maka akan menimbulkan kerugian bagiperusahaan sendiri.

Laudon dan Laudon (2007) mengemukakan bahwa sistem informasi merupakan hal yang penting dalam menjalankan operasional organisasi dan kualitas informasi merupakan jaminan terciptanya kelangsungan perusahaan.

\section{METODE}

Variabel independen terdiri dari kualitas informasi dan kualitas sistem, variabel intervening meliputi kepuasan pengguna, sedangkan variabel dependen adalah net benefit. Objek penelitian yang digunakan adalah PT Bank Mandiri Persero Tbk, dimana akan dikaji mengenai model kesuksesan implementasi sistem informasi perbankan untuk meningkatkan kepuasan dan keuntungan (net benefit) perusahaan.Teknik pengumpulan data dalam penelitian ini dilakukan melalui survey dengan menggunakan kuesioner yang disebar ke sampel yang telah ditentukan. Survey dilakukan secara online menggunakan alat bantu Google Form. Sampel dalam penelitian ini adalah sebagian dari pegawai PT Bank Mandiri Persero Tbk. di seluruh Indonesia yang memiliki pengalaman dalam menggunakan sistem informasi pada PT Bank Mandiri Persero Tbk. dan menempati jabatan atau posisiyang berkaitan. Responden dipilih dengan menggunakan metode simple random sampling, besarnya sampel ditentukan dengan menggunakan rumus Slovin dengan level eror 5\% (level of significance), jumlah sampel pada penelitian ini adalah 369 sampel. Model penelitian dapat dilihat pada gambar berikut: 


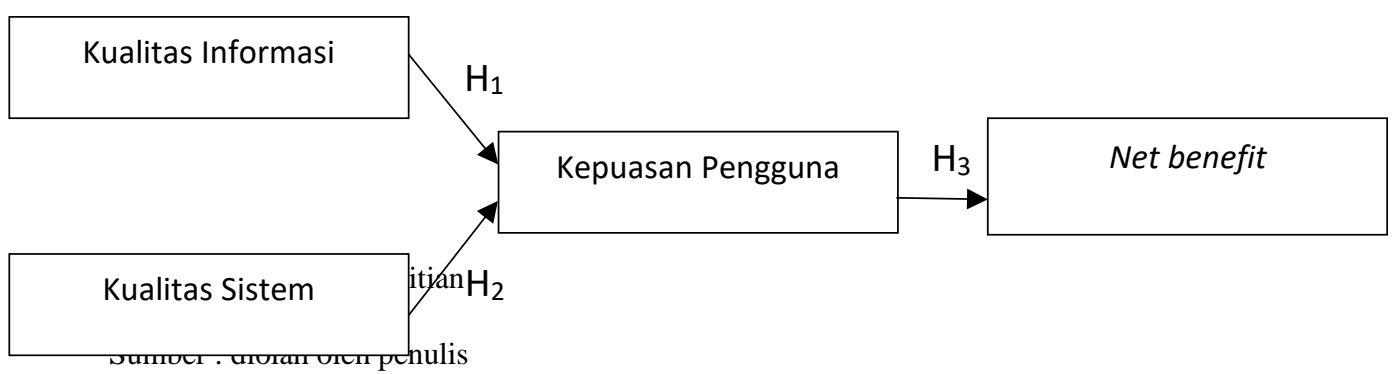

Berdasarkan penelitian DeLone dan McLean (1992; 2003), Mcgill dan Hobbs (2003), Livary (2005), Sambasivan, et al (2010), Jaafreh (2017), Tsai, et al (2017), serta Tam dan Oliveira (2017) yang meneliti tentang model kesuksesan implementasi sistem informasi menggunakan DeLone and McLean Model of Information System Success (DandM IS Success)maka dirumuskan hipotesis sebagai berikut:

$\mathrm{H}_{1}$ : Kualitas Informasi berpengaruh positif terhadap Kepuasan Pengguna

$\mathrm{H}_{2}$ : Kualitas Sistem berpengaruh positif terhadap Kepuasan Pengguna

H3 : Kepuasan Pengguna berpengaruh positif terhadap Net Benefit

\section{HASIL DAN PEMBAHASAN}

Gambar 2 Path Model PLS Algorithm

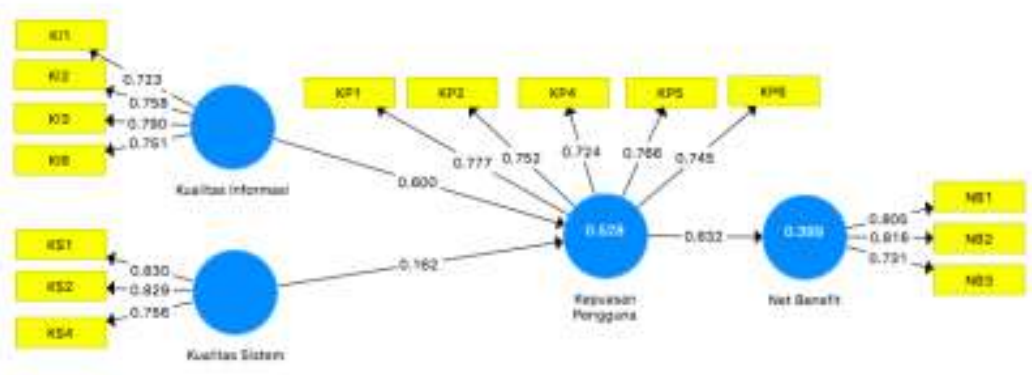

Gambar 3 Average Variance Extracted (AVE) dan Fornell-Larcker Criterion

\begin{tabular}{|l|l|l|l|l|l|l|}
\hline & \multicolumn{2}{|l|}{$\begin{array}{l}\text { Average Variance } \\
\text { Extracted (AVE) }\end{array}$} & \multicolumn{4}{|l|}{ Fornell-Larcker Criterion } \\
\cline { 2 - 7 } & Nilai & Keterangan & $\begin{array}{l}\text { Kepuasan } \\
\text { Pengguna }\end{array}$ & $\begin{array}{l}\text { Kualitas } \\
\text { Informasi }\end{array}$ & $\begin{array}{l}\text { Kualitas } \\
\text { Sistem }\end{array}$ & $\begin{array}{l}\text { Net } \\
\text { Benefit }\end{array}$ \\
\hline $\begin{array}{l}\text { Kepuasan } \\
\text { Pengguna }\end{array}$ & 0.567 & Valid & 0.753 & & & \\
\hline $\begin{array}{l}\text { Kualitas } \\
\text { Informasi }\end{array}$ & 0.571 & Valid & 0.718 & 0.756 & & \\
\hline $\begin{array}{l}\text { Kualitas } \\
\text { Sistem }\end{array}$ & 0.649 & Valid & 0.597 & 0.724 & 0.806 & \\
\hline Net Benefit & 0.617 & Valid & 0.632 & 0.550 & 0.470 & 0.785 \\
\hline
\end{tabular}

\section{Gambar 4 Cross Loading}




\begin{tabular}{|l|l|l|l|l|}
\hline & $\begin{array}{l}\text { Kepuasan } \\
\text { Pengguna }\end{array}$ & $\begin{array}{l}\text { Kualitas } \\
\text { Informasi }\end{array}$ & $\begin{array}{l}\text { Kualitas } \\
\text { Sistem }\end{array}$ & Net Benefit \\
\hline KP1 & 0.777 & 0.526 & 0.441 & 0.560 \\
\hline KP2 & 0.752 & 0.517 & 0.405 & 0.519 \\
\hline KP4 & 0.724 & 0.498 & 0.389 & 0.399 \\
\hline KP5 & 0.766 & 0.579 & 0.537 & 0.452 \\
\hline KP6 & 0.745 & 0.580 & 0.470 & 0.437 \\
\hline KI1 & 0.531 & 0.723 & 0.574 & 0.357 \\
\hline KI2 & 0.558 & 0.758 & 0.504 & 0.473 \\
\hline KI3 & 0.531 & 0.790 & 0.556 & 0.500 \\
\hline KI6 & 0.547 & 0.751 & 0.555 & 0.329 \\
\hline KS1 & 0.474 & 0.575 & 0.830 & 0.396 \\
\hline KS2 & 0.518 & 0.579 & 0.829 & 0.365 \\
\hline KS4 & 0.448 & 0.600 & 0.756 & 0.377 \\
\hline NB1 & 0.509 & 0.476 & 0.420 & 0.805 \\
\hline NB2 & 0.548 & 0.497 & 0.440 & 0.816 \\
\hline NB3 & 0.418 & 0.297 & 0.218 & 0.731 \\
\hline
\end{tabular}

\section{Gambar 5 Composite Reliability dan Cronbach's Alpha}

\begin{tabular}{|l|l|l|l|}
\hline & Composite Reliability & Cronbach's Alpha & Keterangan \\
\hline $\begin{array}{l}\text { Kepuasan } \\
\text { Pengguna }\end{array}$ & 0.868 & 0.809 & Reliabel \\
\hline $\begin{array}{l}\text { Kualitas } \\
\text { Informasi }\end{array}$ & 0.842 & 0.749 & Reliabel \\
\hline Kualitas Sistem & 0.847 & 0.729 & Reliabel \\
\hline Net Benefit & 0.828 & 0.705 & Reliabel \\
\hline
\end{tabular}

\section{Gambar 6 Path Model PLS Bootstrapping}

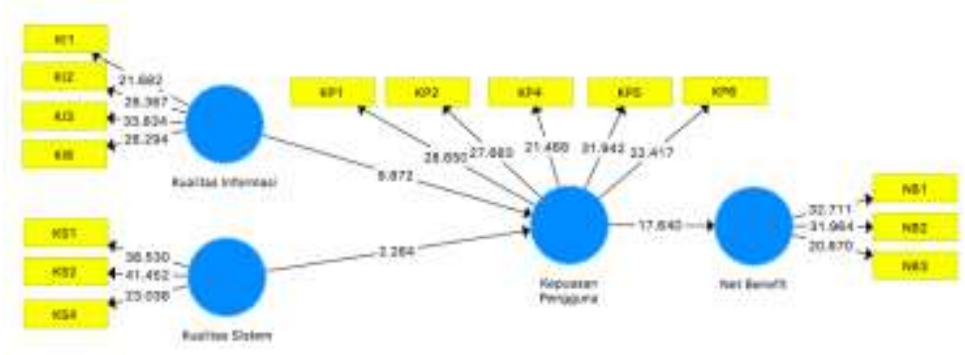

Gambar 7 Koefisien Determinasi $\left(\mathbf{R}^{2}\right)$

\begin{tabular}{|l|l|l|}
\hline & R Square & Adjusted R Square \\
\hline Kepuasan Pengguna & 0.528 & 0.525 \\
\hline Net Benefit & 0.399 & 0.397 \\
\hline
\end{tabular}

Gambar 8 Path Coefficient ( $\beta$ )

\begin{tabular}{|l|l|l|l|l|}
\hline & $\begin{array}{l}\text { Kepuasan } \\
\text { Pengguna }\end{array}$ & $\begin{array}{l}\text { Kualitas } \\
\text { Informasi }\end{array}$ & $\begin{array}{l}\text { Kualitas } \\
\text { Sistem }\end{array}$ & Net Benefit \\
\hline Kepuasan & & & & 0.632 \\
\hline
\end{tabular}




\begin{tabular}{|l|l|l|l|l|}
\hline Pengguna & & & & \\
\hline $\begin{array}{l}\text { Kualitas } \\
\text { Informasi }\end{array}$ & 0.600 & & & \\
\hline Kualitas Sistem & 0.162 & & & \\
\hline Net Benefit & & & & \\
\hline
\end{tabular}

Gambar 9 Uji Original Sample, T-Statistik, dan P-Values

\begin{tabular}{|l|l|l|l|l|l|}
\hline & $\begin{array}{l}\text { Original } \\
\text { Sample (O) }\end{array}$ & $\begin{array}{l}\text { Sample } \\
\text { Mean (M) }\end{array}$ & $\begin{array}{l}\text { Standard } \\
\text { Deviation } \\
(\text { STDEV) }\end{array}$ & $\begin{array}{l}\text { T Statistics } \\
(|\mathrm{O} / \mathrm{STDEV}|)\end{array}$ & P Values \\
\hline $\begin{array}{l}\text { Kepuasan } \\
\text { Pengguna ->Net } \\
\text { Benefit }\end{array}$ & 0.632 & 0.631 & 0.036 & 17.640 & 0.000 \\
\hline $\begin{array}{l}\text { Kualitas } \\
\text { Informasi -> } \\
\text { Kepuasan } \\
\text { Pengguna }\end{array}$ & 0.600 & 0.600 & 0.061 & 9.872 & 0.000 \\
\hline $\begin{array}{l}\text { Kualitas Sistem } \\
->\quad \text { Kepuasan } \\
\text { Pengguna }\end{array}$ & 0.162 & 0.166 & 0.071 & 2.284 & 0.023 \\
\hline
\end{tabular}

\section{Gambar 10 Hasil Pengujian Hipotesis}

\begin{tabular}{|l|l|}
\hline Hipotesis & Keterangan \\
\hline $\begin{array}{l}\text { H1: Kualitas Informasi Berpengaruh Positif Terhadap Kepuasan } \\
\text { Pengguna }\end{array}$ & Didukung \\
\hline $\begin{array}{l}\text { H2: Kualitas Sistem Berpengaruh Positif Terhadap Kepuasan } \\
\text { Pengguna }\end{array}$ & Didukung \\
\hline H3: Kepuasan Pengguna Berpengaruh Positif Terhadap Net Benefit & Didukung \\
\hline
\end{tabular}

\subsection{Kualitas Informasi Berpengaruh Positif Terhadap Kepuasan Pengguna}

Berdasarkan hasil pengujian hipotesis, Koefisien jalur Kualitas Informasi terhadap Kepuasan Pengguna memiliki nilai original sample sebesar 0,600 dan P-Value sebesar 0,000, makadiperoleh kesimpulan bahwa Hipotesis 1 didukung. Hal ini berarti bahwa terdapat pengaruh positif antara Kualitas Informasi terhadap Kepuasan Pengguna, semakin baik Kualitas Informasi maka Kepuasan Pengguna akan meningkat. Hasil pengujian hipotesis menunjukkan bahwa responden merasa puas atas implementasi sistem informasi perbankan untuk meningkatkan kepuasan dan keuntungan (net benefit) perusahaan yang dilihat dari beberapa indikator seperti, kemudahan dalam memperoleh informasi keuangan terbaru, ketersediaan informasi keuangan yang relevan, berguna, dan signifikan, kemudahan dalam memperoleh informasi keuangan yang ringkas dan padat, serta ketersediaan informasi keuangan yang dapat dipertanggungjawabkan dan logis. Dengan demikian, Kualitas Informasi di PTBank Mandiri (Persero) Tbk. yang meliputi, informasi eksternal dan informasi internal. Hasil penelitian ini juga konsisten dengan penelitian Livary (2005), Mulyono (2009), dan Jaafreh (2017) yang membuktikan bahwa kualitas Informasi berpengaruh positif terhadap Kepuasan Pengguna.

\subsection{Kualitas Sistem Berpengaruh Positif Terhadap Kepuasan Pengguna}


Berdasarkan hasil pengujian hipotesis, Koefisien jalur Kualitas Sistem terhadap Kepuasan Pengguna memiliki nilai original sample sebesar 0,162 dan $P$-Value sebesar 0,023, makadiperoleh kesimpulan bahwa Hipotesis 2 didukung. Hal ini berarti bahwa terdapat pengaruh positif antara Kualitas Sistem terhadap Kepuasan Pengguna, semakin baik Kualitas Sistem maka Kepuasan Pengguna akan meningkat. Hasil pengujian hipotesis menunjukkan bahwa responden mengakui kesuksesan implementasi sistem informasi perbankan untuk meningkatkan kepuasan dan keuntungan (net benefit) perusahaan yang dilihat dari beberapa indikator seperti, kemudahan, kenyamanan, dan kecepatan dalam mengakses informasi keuangan, serta mendapatkan manfaat dari adanya informasi keuangan baru atau tambahan yang tersedia.Dengan demikian, Transaction Processing System(TPS) Function, Management Support System (MIS) Function, dan Fixed Asset Information System, Core Banking System (CBS)berpengaruh positif terhadap kepuasan pengguna sistem informasi di PTBank Mandiri (Persero) Tbk.Hasil penelitian ini juga konsisten dengan penelitian Livary (2005), Mulyono (2009), dan Jaafreh (2017) yang membuktikan bahwa Kualitas Sistem berpengaruh positif terhadap Kepuasan Pengguna.

\subsection{Kepuasan Pengguna Berpengaruh Positif Terhadap Net Benefit}

Berdasarkan hasil pengujian hipotesis, Koefisien jalur Kepuasan Pengguna terhadap Net Benefit memiliki nilai original sample sebesar 0,632dan P-Value sebesar 0,000, makadiperoleh kesimpulan bahwa Hipotesis 3 didukung. Hal ini berarti bahwa terdapat pengaruh positif antara Kepuasan Pengguna terhadap Net Benefit, semakin tinggi Kepuasan Pengguna maka Net Benefit akan meningkat. Hasil pengujian hipotesis menunjukkan bahwa Kepuasan Pengguna berpengaruh positif terhadap keberhasilan implementasi sistem informasi perbankanberdasarkan tingkat kepuasan responden terhadap informasi keuangan yang tersedia, kondisi sistem informasi yang memenuhi ekspektasi, manfaat informasi dalam memilih alternatif tindakan yang diambil, ketersediaan informasi keuangan yang jelas, serta rasa bangga dalam menggunakan informasi keuangan dari sistem tersebut. Semakin tinggi tingkat kepuasan responden dan semakin meningkatnya rasa bangga dalam menggunakan informasi keuanganakan meningkatkan net benefit perusahaan karena hal tersebut mencerminkan loyalitas yang baik dari pengguna sistem. Selain itu, semakin baik kondisi sistem informasi, semakin bermanfaatnya informasi yang ada untuk memilih alternatif tindakan yang akan diambil, serta semakin baiknya ketersediaan informasi keuangan yang jelas akan meningkatkan net benefit perusahaan yang tercermin dari informasi yang reliabel dan valid yang mampu digunakan menjadi bahan pertimbangan perusahaan. Dengan demikian, kepuasan pengguna sistem informasi yangmenjabat pada jabatan terkait berpengaruh positif terhadap net benefitpada PT Bank Mandiri (Persero) Tbk.Hasil penelitian ini juga konsisten dengan penelitian Livary (2005), Mulyono (2009), dan Jaafreh (2017) yang membuktikan bahwa Kepuasan Pengguna berpengaruh positif terhadap Net Benefit.

\section{KESIMPULAN}

Hipotesis pertama yang menyatakan bahwa Kualitas Informasi berpengaruh positif terhadap Kepuasan Pengguna terdukung. Hal ini berarti bahwa terdapat pengaruh positif antara Kualitas Informasi terhadap Kepuasan Pengguna, semakin baik Kualitas Informasi maka Kepuasan Pengguna akan meningkat. Hipotesis kedua yang menyatakan bahwa Kualitas Sistem berpengaruh positif terhadap Kepuasan Pengguna terdukung. Hal ini berarti bahwa terdapat pengaruh positif antara Kualitas Sistem terhadap Kepuasan Pengguna, semakin baik Kualitas Sistem maka Kepuasan Pengguna akan meningkat. Hipotesis ketiga yang menyatakan bahwa Kepuasan Pengguna berpengaruh positif terhadap Net Benefit terdukung. Hal ini berarti bahwa terdapat pengaruh positif antara Kepuasan Pengguna terhadap Net Benefit, semakin tinggi Kepuasan Pengguna maka Net Benefit akan meningkat. 


\section{REFERENSI}

\section{Buku}

DeLone, W. H. dan McLean, E. R. (1992). Information Systems Success: The Quest for The Dependent Variable. Information Systems Research, 3 (1), 60-95.

DeLone, W. H. dan McLean, E. R. (2003). The DeLone and McLean Model of Information Systems Success: A Ten-Year Update. Journal of Management Information Systems, 19 (4), 9-30.

Fornell, C. dan Larcker, D.F. (1981). Evaluating structural equation models with unobservable variables and measurement error. Journal of Marketing Research, Vol. 18 No. 1, pp. 39-50.

Ismail, Noor Azizi dan Mat Zin, Rosliza. (2009). Usage of Accounting Information among Malaysian Bumiputra Small and Medium Non-Manufacturing Firms.

Jaafreh, Ali Bakhit. (2017). Evaluation Information System Success: Applied DeLone and McLean Information System Success Model in Context Banking System in KSA.

Kieso, et al. (2007). Akuntansi Intermediate. Jakarta: Erlangga.

Laudon, Kenneth C dan Jane P.Laudon. (2000). Management Information Systems, organization and Technology in The Networked Enterpise. Prentice-Hall, New Jersey, USA.

Laudon, Kenneth C dan Jane P. Laudon. 2007. Sistem Informasi Manajemen. Edisi 10. Terjemahan Chriswan Sungkono dan Machmudin Eka P. Jakarta: Salemba Empat.

Livary, J. (2005). An Empirical Test of The DeLone-McLean Model of Information System Success.Dataabase for Advance in Information System (DFA). ISSN: 1532-0936.Volume 36. ProQuest Company.

McGill, T., Hobbs, V., dan Klobas, J. (2003). Users Developed Application and Information System Success: A Test of Delone and McLean's Model. Information Resource Management Journal, $16(1), 24-45$.

Mulyono, Imam. (2009). Uji Empiris Model Kesuksesan Sistem Informasi Keuangan Daerah (SIKD) Dalam Rangka Peningkatan Transparasi Dan Akuntabilitas Keuangan Daerah. Jurnal dan Prosiding SNA - Simposium Nasional Akuntansi. Volume 12.

Sambasivan, Murali, George Patrick Wemys, and Raduan Che Rose. (2010). User acceptance of a G2B system: a case of electronic procurement system in Malaysia.

Seddon, P. B. dan Kiew, M. Y. (1996). A partial test and development of the DeLone and McLean model of IS success. Australasian Journal of Information Systems, Vol. 4 No. 1, pp. 90-109.

Tam, Carlos dan Tiago Oliveira. (2017). Literature Review of Mobile Banking and Individual Performance. International Journal of Bank Marketing.

Tsai, Gwo Yang, Tsuang Kuo, dan Li-Chen Lin. (2017). The Moderating Effect of Management Maturity on The Implementation of an Information Platform System. Journal of Organizational Change Management. 
For an organizational or government report or document with no author(s):

Www.bankmandiri.co.id 